\title{
Pengaruh Penambahan Bungkil Kelapa Sawit pada Jerami Padi Terfermentasi Terhadap Kualitas Fisik dan Pertambahan Bobot Badan Sapi Peranakan Limousin
}

\section{Influence of the Addition of Palm Oil for Cake on Rice Straw Fermented Physicial Quality and Against Value Added Weights of Cattle Grade Limousin}

\author{
Nurul Khasanah ${ }^{1}$, Drh. Muridi Qomaruddin, $\mathrm{MM}^{2}$, Edy Susanto, S.Pt, M.P \\ ${ }^{1}$ Mahasiswa Fakultas Peternakan \\ ${ }^{2}$ Dosen Pembimbing Utama \\ ${ }^{3}$ Dosen Pembimbing Pendamping \\ Program Studi Peternakan \\ Fakultas Peternakan, Universitas Islam Lamongan (UNISLA)
}

\begin{abstract}
RINGKASAN
Penelitian ini dilaksanakan pada bulan Mei sampai Juni di Kelompok Ternak Sumber Jaya Dusun Pilanggot, Desa Wonokromo, Kecamatan Tikung. Tujuan dari penelitian ini adalah untuk mengetahui pengaruh penambahan bungkil kelapa sawit pada jerami padi terfermentasi terhadap pertambahan bobot badan sapi peranakan Limousin. Kegunaan dari penelitian ini diharapkan agar digunakan sebagai bahan informasi dan pertimbangan tentang campuran bungkil kelapa sawit pada jerami padi terfermentasi tehadap pertambahan bobot badan sapi peranakan Limousin. Materi yang digunakan dalam penelitian ini adalah 18 ekor sapi peranakan Limousin, jerami padi kering, ampas kecap, dan bungkil kelapa sawit. Metode yang digunakan dalam penelitian ini adalah metode percobaan dengan menggunakan RAL, dimana terdiri dari 3 perlakuan yaitu jerami padi terfermentasi tanpa bungkil inti sawit, level penambahan bungkil kelapa sawit $10 \%$ dan 15\%. Dengan 3 kali ulangan dan setiap ulangan diisi 2 ekor sapi. Variabel yang diamati dalam penelitian ini adalah kualitas fisik, $\mathrm{pH}$ dan pertambahan bobot badan sapi peranakan Limousin. Data hasil penelitian dianalisis dengan analisis statistik RAL. Hasil penelitian yang diteliti dapat disimpulkan bahwasannya pengaruh penambahan bungkil kelapa sawit pada jerami padi terfermentasi tidak memberikan pengaruh yang nyata $(\mathrm{P}>0,05)$ terhadap pertambahan bobot badan sapi peranakan Limousin. Akan tetapi pertambahan bobot badan pada sapi peranakan Limousin yang mengkonsumsi pakan jerami padi terfermentasi dengan penambahan bungkil kelapa sawit lebih tinggi dari pada kontrol. Hal ini disebabkan bungkil inti sawit terdapat kandungan protein yang tinggi.
\end{abstract}

Kata Kunci : Bungkil kelapa Sawit, Jerami Padi, Terfermentasi, Kualitas fisik, Pertambahan Bobot Badan, Sapi peranakan Limousin.

\begin{abstract}
This research was carried out in May and June in the Group of Cattle Sumber Jaya Village Pilanggot, village Tikung, district Wonokromo. The purpose of this research is to know the influence of the addition of palm oil for cake on rice straw fermented cow body weight added against cattle grade limousin. The usefulness of this study are expected to be used as material for the information and consideration of palm oil for cake mix on rice straw fermented cow body weight increase of taking action against Straits Limousin. The material used in this study was 6 oxtail cattle grade limousin, rice straw, husks, soy and palm oil for cake. The methods used in this research is a method of experimenting with use of RAL, which consists of 3 treatment namely rice straw fermented without palm kernel for cake, level the addition of palm oil for cake $10 \%$ and 15\%. With 3 times repeats and repeats each recharged 2 cows. The variables observed in this study is the physical quality, $\mathrm{pH}$ and increasing the weight of the body of the cow cattle grade limousin. Data research results were
\end{abstract}


analyzed with the statistical analysis of RAL. Research results are examined, it can be concluded that the influence of the addition of palm oil for cake on rice straw fermented gives no real influence (P $0.05>$ ) against cow body weight increase of cattle grade limousin. But the added weight of the Agency on beef cattle grade limousin who consume rice straw fermented feed with the addition of palm oil for cake is higher than in the control. This is due for cake palm kernel there is a high protein content.

Key words: Oil Palm for cake, Fermented, Rice Straw, Increase Physical Quality, Body Weight, Limousin Cattle Grade.

\section{PENDAHULUAN \\ Latar Belakang Masalah}

Populasi sapi potong di indonesia tahun 2015 menccapai 15.494,29 ekor (Direktorat Jenderal Peternakan dan Kesehatan Hewan, 2015). Untuk populasi sapi potong di Jawa Timur tahun 2015 mencapai 4.326.261 ekor, untuk di Lamongan sendiri mencapai 101.790 ekor (Dinas Peternakan Provinsi Jawa Timur, 2015). Sapi limousin semakin banyak dipilih peternak karena pertambahan bobot badannya tinggi, tingkat efisiensi pakan terbilang bagus, dan presentase daging dalam karkas cukup tinggi (Yulianto dan Saparinto, 2010). Pakan merupakan salah satu faktor yang sangat penting dalam usaha peternakan.

Hijauan adalah sumber pakan utama yang harus tersedia dalam jumlah yang cukup untuk meningkatkan produksi ternak ruminansia. Umumnya hijauan yang diberikan pada ruminansia adalah rumput-rumputan. Hijauan sendiri dibedakan menjadi dua yakni hijauan segar dan hijauan kering. Walaupun demikian masih ada pakan ternak yang jarang dimanfaatkan secara optimal, yaitu limbah hasil produksi padi yakni jerami (Kartadisastra, 1997).

Jerami Padi merupakan salah satu limbah pertanian yang potensial untuk dimanfaatkan sebagai pakan ternak ruminansia. Karakteristik jerami padi ditandai dengan kandungan serat kasar, lignin dan silika yang tinggi (Thalib dkk, 1995) . Bungkil kelapa sawit merupakan limbah hasil perkebunan yakni ikutan dari proses ekstrasi inti sawit. Mirnawati
(2008) dalam Desvita (2011) mengatakan zat makanan yang terkandung dalam bungkil inti sawit cukup bervariasi, tetapi kandungan yang terbesar adalah protein berkisar antara $16,07 \%$.

Selain itu pengolahan bungkil inti sawit juga bertujuan untuk meningkatkan kecernaan, sehingga dapat meningkatkan manfaat bungkil inti sawit sebagai sumber protein yang baik terutama untuk ternak ruminansia.

Tujuan dari penambahan bungkil kelapa sawit pada jerami padi yang difermentasi adalah untuk meningkatkan protein dalam ransum.

\section{METODE PENELITIAN}

\section{Lokasi dan Waktu Penelitian}

Penelitian dilakukan di Kelompok ternak Sumber Jaya Dusun Pilanggot, Desa Wonokromo, Kecamatan Tikung. Pembuatan fermentasi dimulai tanggal 10 April - 30 April 2016. Sedangkan analisis $\mathrm{pH}$ dan uji kualitas fisik penambahan bungkil kelapa sawit pada jerami padi fermentasi dilakukan di Laboratorium Fakultas Peternakan Universitas Islam Lamongan. Untuk percobaan pakan ke sapi dilakukan pada tanggal $3 \mathrm{Mei}-30$ Juni 2016 yaitu selama dua bulan.

\section{Materi Penelitian}

Bahan : Sapi peranakan Limousin jantan sebanyak 18 ekor dengan bobot badan awal kisaran 200-300 kg, Jerami padi fermentasi, Ampas Kecap, Bungkil Kelapa Sawit, Air.

Alat : Sekop, Terpal Poli Etilen (PE), Tangki Air Fiberglass kapasitas 
1000 L, Ember, Selang Air, Gembor Plastik, Gerobak Arco, Timbangan Digital Sapi.

\section{Metode Penelitian \\ Penelitian dilakukan dengan metode penelitian eksperimen. Teknik pengumpulan data pengamtan yang digunakan dalam penelitian ini adalah Metode Observasi, Metode Wawancara Langsung, Metode Kuisioner, Metode Dokumentasi. \\ Variabel Pengamatan dalam penelitian ini adalah pertambahan bobot badan sapi peranakan Limousin.}

Perlakuan

\section{Rancangan Percobaan}

Penelitian ini dilakukan dengan metode Rancangan Acak Lengkap (RAL) terdiri dari 3 perlakuan setiap perlakuan dilakukan 3 kali ulangan. Setiap perlakuan menggunakan 2 ekor sapi peranakan limousin. Dengan perlakuan sebagai berikut :

P0 : Jerami Padi dan Ampas Kecap tanpa penambahan Bungkil kelapa sawit

P1 : Jerami Padi 80\% + Ampas Kecap $10 \%$ + Bungkil kelapa sawit 10\%

P2 : Jerami Padi 75\% + Ampas Kecap $10 \%+$ Bungkil kelapa sawit 15\%

Ulangan

\begin{tabular}{cccc}
\cline { 2 - 4 } & 1 & 2 & 3 \\
\hline $\mathrm{P}_{0}$ & 2 ekor & 2 ekor & 2 ekor \\
$\mathrm{P}_{1}$ & 2 ekor & 2 ekor & 2 ekor \\
$\mathrm{P}_{2}$ & 2 ekor & 2 ekor & 2 ekor
\end{tabular}

\section{HASIL DAN PEMBAHASAN Kualitas Fisik Pakan Uji pH}

Berdasarkan hasil pengamatan yang telah dilakukan terhadap nilai $\mathrm{pH}$ penambahan bungkil sawit pada jerami padi terfermentasi dapat dilihat pada tabel 4.5 .

Tabel 4.5. Data Nilai pH Penambahan Bungkil sawit Pada Jerami Padi Terfermentasi.

\begin{tabular}{cc}
\hline Sampel Perlakuan & $\mathrm{pH}$ \\
\hline $\mathrm{P}_{0}$ (Fermentasi Jerami Tanpa Penambahan Bungkil kelapa sawit) & 5,05 \\
$\mathrm{P}_{1}$ (Jerami Padi 80\% +Ampas Kecap 10\% +Bungkil kelapa sawit 10\%) & 5,24 \\
$\mathrm{P}_{2}$ (Jerami Padi 75\% +Ampas Kecap 10\% +Bungkil kelapa sawit 15\%) & 5,05
\end{tabular}

Sumber : Data diolah primer (2016)

Perlakuan pakan jerami padi terfermentasi dengan penambahan bungkil kelapa sawit diatas tidak berbeda terlalu jauh antar perlakuan, terdapat penurunan $\mathrm{pH}$ yang ditambahkan dengan bungkil kelapa sawit dan ampas kecap yang banyak. Karena bungkil kelapa sawit dan ampas kecap merupakan sumber protein bukan sumber karbohidrat.

Sejalan dengan pendapat Mirnawati (2008) dalam Desvita (2011) mengatakan zat makanan yang terkandung dalam bungkil kelapa sawit cukup bervariasi, tetapi kandungan yang terbesar adalah protein berkisar antara $16,07 \%$. 
Dari hasil penelitian, didapatkan $\mathrm{pH}$ dengan nilai 5,05. Hal ini sesuai dengan penelitian yang dilakukan oleh Asngat (2005) yaitu $\mathrm{pH}$ fermentasi yang baik berkisar antara 4-6.

\section{Uji Organoleptik Profil Responden}

panelis yang terlibat adalah sebagian besar dari mahasiswa Fakultas Peternakan Semester VIII Universitas Islam Lamongan. Penyebaran kuisioner dilakukan pada bulan Juni 2016 di Laboratorium Fakultas Peternakan Universitas Islam Lamongan.

Tabel 4.6 Klasifikasi panelis

\begin{tabular}{ccc}
\hline Jenis Kelamin & Jumlah & Presentase \\
\hline Laki-Laki & 11 & $73,33 \%$ \\
Perempuan & 4 & $26,67 \%$ \\
Total & 15 & 100
\end{tabular}

\section{Hasil Pengamatan Uji Organoleptik}

Hasil pengamatan uji organoleptik pada penambahan bungkil terfermentasi dapat dilihat pada tabel 4.7 .

kelapa sawit pada jerami padi

Tabel 4.7. Hasil Pengamatan Uji Organoleptik

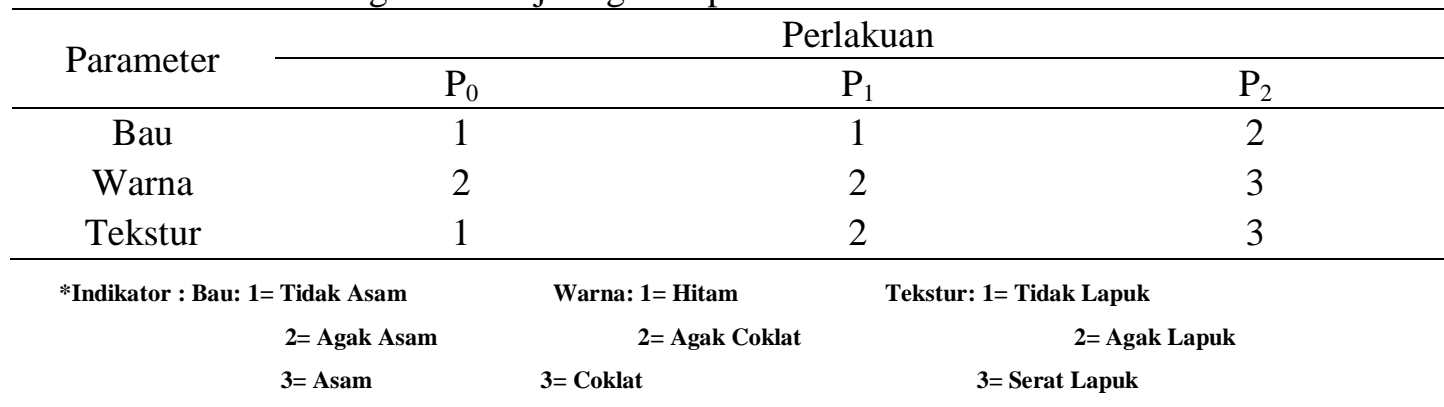

Sesuai dengan pendapat

Widiyanto (1996) dalam Muntaqo, dkk (2015) menyatakan ciri-ciri hasil fermentasi jerami padi yang baik adalah beraroma harum atau beraroma tape (asam), warna kuning kecoklatan, teksturnya lemas dan tidak berjamur. Pembuatan fermentasi pakan yang dilakukan telah berhasil. Berdasarkan pendapat Widiyanto (1996) dalam Muntaqo, dkk (2015) tersebut dapat disimpulkan bahwa bau, warna dan tekstur pada fermentasi pakan tersebut sudah sesuai dengan pendapat Widiyanto (1996) dalam Muntaqo, dkk (2015), walaupun baunya masih agak asam. Adapun baunya agak asam disebabkan karena kontrol fermentasi yang tidak sama persis antar perlakuan seperti kelembaban udara, suhu, penutup pada pakan, dan kadar air yang ditambahkan pada saat fermentasi.

\section{Pengaruh Perlakuan Terhadap Pertambahan Bobot Badan Sapi Peranakan Limousin}

Data penelitian pertambahan bobot badan sapi Peranakan Limousin dan hasil uji statistiknya dapat dilihat pada Tabel 4.8 berikut ini. 
Tabel 4.8 Data Pertambahan Bobot Badan Sapi Peranakan Limousin (kg/ekor/hari)

\begin{tabular}{cccccc} 
Perlakuan & \multicolumn{3}{c}{ Ulangan } & \multirow{2}{*}{ Total } & Rataan \\
\cline { 2 - 4 } & 1 & 2 & 3 & & 0,62 \\
$\mathrm{P}_{0}$ & 0,50 & 0,53 & 0,65 & 0,55 \\
$\mathrm{P}_{1}$ & 0,65 & 0,45 & 0,58 & 1,68 & 0,56 \\
$\mathrm{P}_{2}$ & 0,77 & 0,68 & 1,09 & 2,54 & 0,85 \\
\hline Total & 1,92 & 1,66 & 2,29 & 5,87 & 0.65
\end{tabular}

Sumber : Data diolah Primer

$\mathrm{P}_{0}$ (jerami padi dan ampas kecap tanpa penambahan bungkil kelapa sawit)

$\mathrm{P}_{1}$ (jerami $80 \%+$ ampas kecap $10 \%+$ bungkil kelapa sawit $10 \%$ )

$\mathrm{P}_{2}$ (jerami $75 \%+$ ampas kecap $10 \%$ + bungkil kelapa sawit 15\%)

Berdasarkan hasil uji statistik dan data pada tabel 4.8 menunjukkan bahwa pengaruh pemberian pakan dengan perlakuan diatas tidak berbeda nyata $(\mathrm{P}>0,05)$ pada pertambahan bobot badan Sapi Peranakan Limousin. Namun, terdapat peningkatan bobot badan seiring dengan penambahan bungkil kelapa sawit.

Hal ini dapat terlihat pada $\mathrm{P}_{0}$ bobot badan Sapi Peranakan Limousin meningkat sebanyak $0,55 \mathrm{~kg}$ dan $\mathrm{P}_{1}$ bobot badan sapi Peranakan Limousin meningkat sebanyak $0.56 \mathrm{~kg}$. Pada $\mathrm{P}_{2}$ mengalami peningkatan sebanyak $0.85 \mathrm{~kg}$. Hasil analisis statistik pada tabel 4.8 menunjukkan bahwa pertambahan bobot badan sapi yang di beri pakan dengan perlakuan diatas sekitar 0,65 kg/ekor/hari.

Menurut Yulianto dan Saparinto, (2010) bahwa Sapi Peranakan Limousin memiliki pertambahan bobot badan harian (PBBH) berkisar 0,80-1,60 kg/hari dengan presentase karkas daging yang tinggi yaitu 48-55\%. Berdasarkan hal tersebut, hasil penelitian ini belum mencapai pertambahan bobot badan standart karena konsumsi protein dan energinya masih perlu ditingkatkan.

\section{KESIMPULAN DAN SARAN}

\section{Kesimpulan}

Berdasarkan hasil dari penelitian yang diteliti, dapat disimpulkan bahwasannya pengaruh penambahan bungkil kelapa sawit pada jerami padi terfermentasi tidak memberikan pengaruh yang nyata $(\mathrm{P}>0,05) \quad$ terhadap pertambahan bobot badan sapi peranakan Limousin. Namun demikian terdapat peningkatan bobot badan seiring dengan peningkatan penambahan bungkil kelapa sawit.

Hal ini disebabkan bungkil kelapa sawit terdapat kandungan protein yang tinggi. Untuk uji $\mathrm{pH}$ terdapat penurunan $\mathrm{pH}$ pada perlakuan $\mathrm{P}_{2}$ yaitu 5,05. Uji kualitas fisik pakan sudah bagus dengan baunya agak asam, warna coklat dan tekstur serat lapuk, walaupun baunya masih agak asam. Adapun baunya agak asam disebabkan karena kontrol fermentasi yang tidak sama persis antar perlakuan.

\section{Saran}

Saran yang dapat diberikan dalam penggunaan bungkil kelapa sawit pada jerami padi tefermentasi untuk pertambahan bobot badan sapi adalah :

1. Sebaiknya bungkil kelapa sawit diberikan lebih dari $15 \%$ untuk mendapatkan peningkatan bobot badan lebih dari $0,85 \mathrm{~kg}$. Namun perlu dihitung efisiensi biaya ransumnya.

2. Sebaiknya dalam pembuatan fermentasi pakan harus memperhatikan suhu, penutup pakan, dan kadar air yang ditambahkan pada saat fermentasi. Sehingga hasil fermentasi pakannya baik.

DAFTAR PUSTAKA

Asngat, Aminah. 2005. Perubahan Kadar

Protein Pada Fermentasi Jerami Padi Dengan 
Penambahan Onggok Untuk Makanan Ternak. Pendidikan Biologi FKIP. Universitas Muhammadiyah Surakarta.

Direktorat Jenderal Peternakan dan Kesehatan Hewan, 2015. Populasi Sapi Potong dan Produksi Daging. Surabaya.

Dinas Peternakan Provinsi Jawa Timur, 2015. Data Statistik Populasi ternak Di Lamongan. Surabaya.

Desvita, Mariza. 2011. Respons Broiler

Pada Ransum Yang

Mengandung Produk

Fermentasi Bungkil Inti Sawit Yang Ditambah Asam Humat.

Fakultas Peternakan. Universitas Andalas. Padang.

Kartadisastra, H. R., 1997. Penyediaan dan Pengelolaan Pakan Ternak Ruminansia. Kanisius. Yogyakarta.

Muntaqo, Imam., M. Aflahuddin, Denies Chrispatra, Nurus Sobah, Bastian Titus A.P. 2015. Teknologi Dan Fabrikasi Pakan. Laboratorium Teknologi Makanan Ternak. Bagian Nutrisi Dan Makanan Ternak. Fakultas Peternakan. Universitas Gadjah Mada. Yogyakarta.

Thalib,A., Y. Widiawati, H. Hamid, D. Suherman, dan J . Bestari . 1995 . Efek Kombinasi Rumen SapiKerbau Terhadap Kecernaan Jerami Padi. Prosiding Seminar Nasional Peternakan dan Veteriner. Puslitbang Peternakan Bogor. Pp 617-625.

Yulianto, Purnawan dan Cahyo Saparinto. 2014. Beternak Sapi Limousin. Penebar Swadaya. Semarang. 